\title{
Determinants of Loan Repayment among Small Holder Cooperative Farmers in Remo Division, Ogun State, Nigeria
}

\author{
S. U. Isitor ${ }^{1}$, A. O. Otunaiya ${ }^{2}$, A. G. Adeyonu ${ }^{1} \&$ E. F. Fabiyi ${ }^{1}$ \\ ${ }^{1}$ Department of Agricultural Economics and Extension, College of Agricultural Sciences, Landmark University, \\ Omu-Aran, Kwara State, Nigeria \\ ${ }^{2}$ Department of Agricultural Economics and Farm Management, College of Agricultural Sciences, Olabisi \\ Onabanjo University, Yewa Campus, Ayetoro, Ogun State, Nigeria \\ Correspondence: S. U. Isitor, Department of Agricultural Economics and Extension, College of Agricultural \\ Sciences, Landmark University, Omu-Aran, Kwara State, Nigeria. E-mail: uisitor@hotmail.com
}

Received: October 14, 2015 Accepted: November 9, 2015 Online Published: December 15, 2015

doi:10.5539/jas.v8n1p92 URL: http://dx.doi.org/10.5539/jas.v8n1p92

\begin{abstract}
This study investigated the factors that are crucial in improving small holder cooperative farmers' loan repayment in Remo Division of Ogun state, Nigeria. Primary data used for the study were collected with the aid of well-structured questionnaire. Multi-stage sampling techniques were used to select the 120 respondents. The data were analyzed using descriptive statistics and probit regression model. The results of the descriptive analysis showed that about $56 \%$ of the respondents were able to repay their loans promptly while the rest were not. The respondents' mean age stood at 47 years, the majority of them are males and married with fair level of education. The majority of smallholder farmers in the study area had been farming for more than 20 years, while the household size for the majority of them was 4-6 members with average family size of 5. The results of the probit regression analysis revealed that age, level of education, farming experience, net farm income and loan size obtained were the major factors that increase the likelihood of loan repayment, while the number of family dependants reduces the probability of repayment. To improve loan repayment ability in the study area, this study recommended improvement in human capacity development as well as sensitization of the farmers in the study area about the importance of education.
\end{abstract}

Keywords: loan repayment ability, small-holder farmers, cooperative society, Ogun State, Nigeria

\section{Introduction}

The agricultural sector in Nigeria is the most important non-oil economic activity, it is also the single largest employer of labor forces, employing about 70 percent of its workforce (NBS, 2014; USDA, 2013) and contributed $40.07 \%$ and $22 \%$ (pre and post debasing period respectively) of Gross Domestic Products (GDP) in 2010 and 2014 respectively (NBS, 2014). Rahji and Fakayode (2009) noted that small-scale farmers play a dominant role in this contribution. According to Odoemenem and Obinne (2010), small-holder farmers' productivity and growth are hindered by limited access to credit facilities. Badiru (2010) revealed that friends and relatives are the most important sources of credit to the farmers followed by cooperatives and NGO.

Over the years, a key issue that has emerged is the question of loan repayment. Loan repayment performance could be influenced by a myriad of factors such as interest rate, unstable prices of agricultural commodities, and the social relations and responsibilities of the borrowers among others (Ugbomeh et al., 2008; C. Tundui \& H. Tundui, 2013; Awoke, 2004). The question of repayment of loan by farmers is one of the important issues since it influences access to credit by the farmers (Awunyo-Vitor 2012; Saleem et al., 2014).

Onyeagocha et al. (2012) noted that one way to tackle the loan repayment challenges is to investigate the factors which affect loan repayment. Some previous studies; Eze and Ibekwe (2007), Olagunju and Adeyemo (2007), J. O. Oladeebo and O. E. Oladeebo (2008), Afolabi (2008, 2010), Akerele et al. (2014), Anigbogu et al. (2014) and Ojiako et al. (2014) to mention a few, revealed that income, sex, farm size, age of farmers, years of farming experience, size of loan, household size, and level of education of farmers directly explained loan repayment ability, others showed them to have inverse relation on repayment. To the best of our knowledge, little or nothing is known about the subject matter in the study area. Therefore, this study examined the determinants of loan 
repayment among smallholder cooperative farmers in Remo Division, Ogun state, Nigeria.

\section{Methodology}

\subsection{The Study Area}

The study was carried out in Remo Division of Ogun State, Nigeria. Remo division was purposely selected because it is one of the most populous divisions in Ogun State and predominantly rural in nature and have high presence of smallholder farmers that belong to farmers' cooperative society. The division consists of 3 Local Government Areas (LGAs) namely: Ikenne, Sagamu and Remo North. The population was about 178,412 as at the 2006 census with land size of approximately 97, 298 hectares (NPC, 2006).

\subsection{Data Collection and Sampling Techniques}

The data used for this study were mainly from the primary source. They were obtained through the use of pre-tested, well-structured questionnaire which was administered by trained enumerators. The tool was used to collect information on respondents' socioeconomic characteristics, amount of loan given to farmers, whether or not farmers were able to pay for their loans on time, interest charged on loans given to them, timeliness of disbursement of loans, farm size and other factors influencing loan repayment by small holder cooperative farmers in Remo division of Ogun State.

Multistage sampling technique was employed to select the respondents. Each of the 3 LGAs was regarded as a subunit of the study area, while all the smallholder cooperative farmers in each of the subunits formed the sample frame for the study. The first stage of the sampling was the random selection of 12 wards from the 35 wards of the study area using probability proportionate to size of the LGAs. The lists of the farmers' cooperative society members were obtained from the selected wards with the help of the community leaders and executive members of the society. The second stage involved the random selection of $50 \%$ of cooperators who borrowed money between 2011-2013 planting seasons. Data were collected in 2014 well above a year after the loans were collected. The stage that follows was the stratification of the borrowers into defaulters and non-defaulters. The fourth and final stage was the use of simple random sampling technique to select 145 respondents which revealed defaulters and non-defaulters using probability proportionate to size of each stratum. However, 120 questionnaires were found to be useful for the analysis.

\subsection{Analytical Procedure}

The data collected were analyzed using descriptive statistics such as frequency and percentages to describe the socioeconomic characteristics of respondents while the probit regression model was used to analyze the factors influencing loan repayment performance of the farmers. The cooperative farmers' ability to pay for the loan borrowed at the right time is dichotomized, involving two mutually exclusive alternatives. The farmer is either able to pay for loan at the right time or not. Models for estimating such phenomena in which the dependent variable is binary have been propounded (Maddala, 2005; Asante et al., 2011). The framework for such analysis has its root in the threshold theory of decision making in which a reaction occurs only after the strength of a stimulus increases beyond the individual's reaction threshold (Hill \& Kau, 1981). This means that every individual when faced with a choice has a reaction threshold influenced by several factors (Asante et al., 2011). This yields a binary dependent variable, $y_{i}$ which takes on the values of zero (small holder cooperative farmer's inability to pay for his/her loan) and one (a small holder farmer's ability to pay for his/her loan). The Probit procedure computes maximum likelihood estimates of the parameters $\beta$ and $C$ of the probit equation using a modified Newton-Raphson algorithm. When the response $Y$ is binary, with values 0 and 1 , the probit equation is,

$$
p=\operatorname{Pr}(Y=0)=C+(1-C) F\left(X^{\prime} \beta\right)
$$

Where, $\beta$ is a vector of parameter estimates; $F$ is a cumulative distribution function (the normal, logistic, or extreme value); $X$ is a vector of explanatory variables; $p$ is the probability of a response; $C$ is the natural (threshold) response rate.

Given such a specification, the parameters for estimating this model were determined using the maximum likelihood estimation approach following (Wongnaa \& Awunyo-Vitor, 2013). The dependent variable is an unobserved latent variable that is linearly related to $y_{i}$ by the equation:

$$
y_{i}=\beta_{i} x_{i}+u_{i}
$$

Where, $u_{i}$ is a random disturbance term. The observed dependent variable is determined by whether $y_{i}$ exceeds a threshold value or not:

$$
y_{i}=\left(1 \text { if } y_{i}^{*}>0 \text {, and if } y_{i}^{*} \leq 0\right)
$$


Where, $y_{i}^{*}$ is the threshold value for $y_{i}$ and is assumed to be normally distributed.

According to Maddala (2005) and Asante et al. (2011), common models for estimating such parameters include probit (standard normal), logit (logistic) and tobit (extreme value).

\subsection{The Probit Model}

Following Maddala (2005); Asante et al. (2011); Wongnaa and Awunyo-Vitor (2013), this study adopted the probit model. It was adopted partly because of its ability to constrain the utility value of the ability to pay for loan variable to lie within 0 and 1 , and its ability to resolve the problem of heteroscedasticity. The other advantages of the probit model include believable error term distribution as well as realistic probabilities. The probit model is specified as:

$$
\begin{gathered}
P_{i}=P\left(y_{i}^{*}<y_{i}\right) \\
P_{i}=P\left(y_{i}^{*}<\beta_{0}+\beta_{i} x_{j i}\right)=F\left(y_{i}\right) \\
P_{i}=F\left(0 y_{i}\right)=\frac{1}{\sqrt{2 \prod}} \int_{-\infty}^{z_{i}} e \frac{s^{2}}{2} d s
\end{gathered}
$$

Where, $P_{i}$ is the probability that an individual will pay for loan collected or not, $s$ is a random variable normally distributed with mean zero and unit variance, $y_{i}$ is the dependent variable (ability to pay for loan collected or not), $y_{i}^{*}$ is the threshold value of the dependent variable.

To obtain an estimate of the index $z_{i}$, the inverse of the cumulative normal function is used:

$$
y_{i}=F^{-1}\left(P_{i}\right)=\beta_{0}+\beta_{i} x_{i}+u_{i}
$$

However, unlike traditional regression coefficients, the probit coefficients cannot be interpreted directly as estimates of the marginal effects of changes in the explanatory variables on the expected value of small holder farmers ability to pay for loan or not. To this effect, the relative effect of each explanatory variable on the likelihood that a farmer will be able to repay his or her loan (marginal effect) was calculated and reported following (Wongnaa \& Awunyo-Vitor, 2013). This was done by taking the partial derivatives of equation 6 above with respect to each explanatory variable as shown below:

Where, $P_{i}$ is the mean dependent variable.

$$
\frac{\partial P_{i}}{\partial x_{i j}} \beta_{i j} f\left(Z_{i}\right)
$$

The value is given in the probit results as:

$$
\begin{gathered}
f\left(Z_{i}\right)=F^{-1}\left(P_{i}\right) \\
Z_{i}=\beta_{0}+\beta_{1} x_{1}+\beta_{2} x_{2}+\beta_{3} x_{3}+\ldots+\beta_{k} x_{k}
\end{gathered}
$$

$f\left(Z_{i}\right)=$ Density function of the standard normalvariable which is stated as:

$$
f\left(Z_{i}\right)=\frac{1}{\sqrt{2 \Pi}} e^{-\frac{1}{2} Z^{2}}
$$

The empirical model is stated explicitly as:

$$
Z_{i}=\beta_{0}+\beta_{1} x_{1}+\beta_{2} x_{2}+\beta_{3} x_{3}+\beta_{4} x_{4}+\beta_{5} x_{5}+\ldots+\beta_{11} x_{11}+\beta_{12} x_{12}+\beta_{13} x_{13}+\beta_{14} x_{14}+U_{i}
$$

Where,

$Z_{i}=$ farmers' loan repayment ability (able to pay $=1,0$ otherwise);

$x_{1}=$ Age (years);

$x_{2}=\operatorname{Sex}($ Male $=1,0$ otherwise);

$x_{3}=$ Years of schooling;

$x_{4}=$ Marital status (Married $=1,0$ otherwise);

$x_{5}=$ Farming experience (years);

$x_{6}=$ Farm size (Hectares);

$x_{7}=$ No of wives;

$x_{8}=$ No of children;

$x_{9}=$ No of dependants;

$x_{10}=$ Other means of livelihood (Yes=1, 0 otherwise); 
$x_{11}=$ Extension visits $($ Yes $=1,0$ otherwise $)$

$x_{12}=$ Net farm income $(\mathrm{N})$;

$x_{13}=$ Loan size $(\mathrm{N})$;

$x_{14}=$ Interest rate $(\mathrm{N})$;

$U i=$ Error term.

\section{Results and Discussion}

\subsection{Descriptive Analysis}

The descriptive analysis of the socio-economic characteristics of small holder cooperative farmers in Remo division of Ogun state is presented in Table 1 below. The results of the analysis show that the majority of the respondents $(56 \%)$ were in the age range of $41-50$ years while the mean age stood at 46.5 years. The implication is that the small holder cooperative farmers in the study area are still relatively young and energetic who are likely going to work effectively to increase their yields ceteris paribus. The results suggest a promising future for farming in Remo. The findings compare well with that of J. O. Oladeebo and O. E. Oladeebo (2008), who reported that the mean age of farmers is 47 years but a bit higher than the mean age of 44 years reported by (Abula et al., 2013). This however is contrary to the growing evidence of ageing farming population in most parts of rural Nigeria as reported by (Adeyonu, 2012). About two-thirds of the respondents are males and the rest are females. The results show that more men are involved in farming in Remo than women. The results concur with those of Afolabi (2010), Ojiako et al. (2014) who observed that male dominance in farming activities may be due to the drudgery nature of agriculture. However, this may not be unconnected with the cultural belief that males are the supposed breadwinners of their homes and are saddled with responsibility of putting food on the table and providing for other needs of the family (Adeyonu, 2012; Adofu et al., 2012). This may however, have negative influence on their ability to repay the loan borrowed.

Well above three-quarters of the respondents are married. This may be due to the fact that married men are perceived to be settled, more matured, more trustworthy and have more potential for family labour supply. This finding corroborate a similar study by J. O. Oladeebo and O. E. Oladeebo (2008), Afolabi (2010) and Wongnaa Awunyo-Vitor (2013) who observed that more of the farmers who are cooperative members are married. This results show that most of the farmers in the division are married and these married farmers are likely to spend more of their income on their families. Since married farmers are likely to have a larger family size, they will have higher expenses than single farmers. Therefore single farmers are likely to have better repayment ability than married farmers. A large number of the smallholder cooperative farmers in Remo are educated. This shows that the majority of the respondents had received formal education and is likely to have adequate knowledge of loan acquisition and management, thereby making them able to repay the loans given to them. Also, the high level of literacy predisposes some level of managerial ability in the farm business. Afolabi (2010), Acquah and Addo (2011) and Abula et al. (2013) obtained similar results.

Furthermore, the results show that about $70 \%$ of the smallholder cooperative farmers in Remo had family size of 4-6. This shows that a greater percentage of the farmers have large family sizes and this could likely raise their total expenses and negatively affect their loan repayment ability. The mean family size was six which is higher than the recommended national average of four (Alabi \& Haruna, 2005). Well above average of the respondents have spent more than 20 years in farming with the mean farming experience of about 17 years. This means that quite a large number of them have been farming for fairly a long time. The high level of farming experience could positively influence loan repayment abilities of the farmers in the study area. This contradicts the results of Ojiako et al. (2014) and Wongnaa and Awunyo-Victor (2013) who found the average agricultural years of experience of farmers to be about ten years.

More than $50 \%$ of the sample respondents were able to repay their loan within the stipulated time, while the remaining were not. This implies that the number of smallholder farmers who were able to repay their loans is more than those who were unable to repay. This is in line with the results of Wongnaa and Awunyo-Victor (2013) who found a high loan repayment rate of about $59 \%$ in their investigation of the determinants of loan repayment decisions among smallholder farmers. Sadly, well above three-quarters of the smallholder cooperative farmers in Remo reported that they did not have access to extension workers. Not surprisingly, almost all the respondents had other means of livelihood apart from farming. This may perhaps be as a result of high risks and uncertainties associated with farming. The farmers took to diversification to minimize shock from the effect of unpredictable income from farming. 
Table 1. Socio-economic characteristics of cooperative farmers

\begin{tabular}{|c|c|c|}
\hline Variables & Frequency & Percent \\
\hline \multicolumn{3}{|l|}{ Age (Years) } \\
\hline$<30$ & 11 & 9.2 \\
\hline $31-40$ & 19 & 15.8 \\
\hline $41-50$ & 56 & 46.7 \\
\hline $51-60$ & 29 & 24.2 \\
\hline Sample size & 120 & 100.0 \\
\hline Mean & 46.5 & \\
\hline Standard deviation & 15.03 & \\
\hline \multicolumn{3}{|l|}{$\operatorname{Sex}$} \\
\hline Male & 73 & 60.8 \\
\hline Female & 47 & 39.2 \\
\hline \multicolumn{3}{|l|}{ Marital status } \\
\hline Single & 8 & 6.7 \\
\hline Married & 87 & 72.5 \\
\hline Divorced & 13 & 10.8 \\
\hline Widow/widower & 12 & 10.0 \\
\hline \multicolumn{3}{|l|}{ Years of schooling } \\
\hline 0 & 18 & 15.0 \\
\hline $1-6$ & 45 & 37.5 \\
\hline $7-12$ & 37 & 30.8 \\
\hline$>12$ & 20 & 16.7 \\
\hline Mean & 6.39 & \\
\hline Standard deviation & 2.54 & \\
\hline \multicolumn{3}{|l|}{ Household size } \\
\hline$<4$ & 25 & 20.8 \\
\hline $4-6$ & 69 & 57.5 \\
\hline $7-8$ & 20 & 16.7 \\
\hline$>8$ & 6 & 5.0 \\
\hline Mean & 5.7 & \\
\hline Standard deviation & 1.98 & \\
\hline \multicolumn{3}{|c|}{ Farming experience (years) } \\
\hline$<5$ & 5 & 4.2 \\
\hline $6-10$ & 12 & 10.0 \\
\hline $11-15$ & 20 & 16.7 \\
\hline $16-20$ & 26 & 21.7 \\
\hline$>20$ & 57 & 47.5 \\
\hline Mean & 16.6 & \\
\hline Standard deviation & 7.4 & \\
\hline \multicolumn{3}{|l|}{ Ability to repay loan } \\
\hline Yes & 67 & 55.8 \\
\hline No & 53 & 44.2 \\
\hline \multicolumn{3}{|l|}{ Extension visits } \\
\hline Yes & 19 & 15.8 \\
\hline No & 101 & 84.2 \\
\hline \multicolumn{3}{|c|}{ Other means of livelihood } \\
\hline Yes & 115 & 95.8 \\
\hline No & 5 & 4.2 \\
\hline
\end{tabular}

Source: Data Analysis (2015). 


\subsection{Determinants of Loan Repayment among Smallholder Cooperative Farmers}

Table 2 shows the results of the analysis of factors affecting loan repayment among the respondents. Out of the 14 variables included in the model, only six variables are significant. As shown in the table; age, level of education, years of farming experience, net farm income and loan size of smallholder cooperative farmers are positively associated with their probability to repay loan at the right time. A one-year increase in the farmers' age, level of education and years of farming experience ceteris paribus, will increase the likelihood of being able to repay the loan by $6.5 \%, 98.4 \%$ and $7.9 \%$ respectively. The implication is that educated older farmers with many years of farming experience have better loan repayment abilities than less educated young and inexperienced farmers. This could be as a result of accumulated knowledge acquired in school and in many years of farming experience that these older farmers' have. The results concur with those of Otunaiya et al. (2014) and Wongnaa and Awunyo-Vitor (2013) who opined that there is positive association between age and ability to repay loan.

Not surprisingly, number of dependants is inversely correlated to farmers' ability to repay their loans. Increasing farmers' dependants by one person decreases the likelihood of been able to repay loan by $12.2 \%$. This implies that the smaller the dependants of the farmers' family, all other things been equal, the higher the probability that they will be able to repay loans and vice versa. This may not be unconnected with the fact that large number of dependants increased the household heads' domestic responsibilities and thereby constituted leakage to the households' income. This in turn resulted in default in loan repayment. This is in line with earlier evidence by J. O. Oladeebo and O. E. Oladeebo (2008), Ugbomeh et al. (2008), Wongnaa and Awunyo-Vitor (2013) and Otunaiya et al. (2014) who reported that farmers' household size is inversely related with their loan repayment ability. The findings, however, contradict Afolabi (2008) who showed a direct association between family size and loan repayment ability. Also, educational level is positively related to small holder farmers' ability to repay their loans. Increasing farmers' educational level by one year has the effect of increasing the likelihood of respondents being able to repay loan by $98.4 \%$. This implies that a farmer will likely have greater loan repayment ability when he or she has a higher educational level and vice versa, ceteris paribus. This may perhaps be due to the understanding on the part of the educated farmers the importance of prompt repayment of the loan obtained. Otunaiya et al. (2014) and Wongnaa and Awunyo-Vitor (2013) obtained similar results. However, the variables representing the net farm income and loan size obtained by the sampled farmers are significant at $1 \%$ and $10 \%$ respectively. The results imply that increase in the net farm income and loan size obtained by the farmers increases the likelihood that the farmers will repay the loan within the stipulated time.

Table 2. Probit estimates of factors influencing loan repayment by smallholder cooperative farmers

\begin{tabular}{lll}
\hline Variables & Marginal effects & t- Statistic \\
\hline (Constant) & & -0.803 \\
Age & 0.065 & $1.611^{*}$ \\
Sex & 0.021 & 0.626 \\
Level of education & 0.984 & $26.433^{* * *}$ \\
Marital status & -0.030 & -0.890 \\
Farming experience & 0.079 & $1.904^{*}$ \\
Farm size & 0.000 & 0.012 \\
Number of wives & -0.018 & -0.547 \\
Number of children & -0.020 & -0.417 \\
Number of dependent & -0.122 & $-3.115^{* * *}$ \\
Other means of livelihood & 0.039 & 0.988 \\
Extension visit & 0.002 & 0.053 \\
Net farm income & 0.824 & $24.213^{* * *}$ \\
Loan size & 0.038 & $1.756^{*}$ \\
Interest rate & 0.007 & 0.211 \\
Pseudo R-Square & 0.895 & \\
Log likelihood & -95.813 & \\
\hline
\end{tabular}

Note. $* * *$ Significant at $1 \%$, and $*$ at $10 \%$.

Source: Data Analysis (2015). 


\section{Conclusion and Recommendations}

This study investigated the determinants of loan repayment among small holder cooperative farmers in Remo, Ogun State Nigeria. The results of the study showed that the majority of the smallholder farmers are males while their mean age stood at about 47 years with mean household size of 6 members. About $56 \%$ of the respondents were able to repay the loans borrowed as at when due, while a mere $16 \%$ were visited by extension agents within the time loans were borrowed and repaid, with only about $15 \%$ of them with no formal education. The results also showed that age, level of education, farming experience, net farm income and loan size obtained by farmers positively determined the farmers' ability to repay loans while number of farmers' family dependants reduced the likelihood to repay loans.

Based on these, it was suggested that skill - building and training of human resources be put in place as this is very paramount both in increasing their chances of earning more income from their enterprises, promote agricultural development and improve their ability to repay loans. Furthermore, the ongoing effort by the stakeholders about sensitizing the populace about the benefits of small family size should be intensified as this will help in increasing small holder farmers' ability to repay loans and improve agricultural development in the study area and the country as a whole.

\section{References}

Abula, M., Otitolaiye, J. O., Ibitoye, S. J., \& Orebiyi, J. S. (2013). Repayment Performance of Rural Farmers Loan Beneficiaries of Microfinance Banks in Kogi State, Nigeria. International Journal of Farming and Allied Sciences, 2(5), 104-110.

Acquah, H. D., \& Addo, J. (2011). Determinants of Loan Repayment Performance of Fishermen: Empirical Evidence from Ghana. Cercetări Agronomice în Moldova, 44(4), 148.

Adeyonu, A. G. (2012). Gender Dimensions of Time Allocation of Rural Farming Households in Southwest Nigeria. Current Research Journal of Social Sciences, 4(4), 269-276.

Adofu., I., Orebiyi, J. S., \& Otitolaiye, J. O. (2012). Repayment Performance and Determinants of Food Crop Farmers Loan beneficiaries of Nigeria Agricultural Cooperative and Rural Development Bank (NACRDB) in Kogi State, Nigeria (2008-2010). Journal of Development and Agricultural Economics, 4(5), 20-40.

Afolabi, J. A. (2008). Analysis of Loan Repayment among Small Scale Farmers in South Western Nigeria: A Discriminant Approach. J. Soc. Sci., 17(1), 83-88.

Afolabi, J. A. (2010). Analysis of Loan Repayment among Small Scale Farmers in Oyo State, Nigeria. J. Soc. Sci., 22(2), 115-119.

Akerele, E. O., Aihonsu, J. O. Y., Ambali, O. I., \& Oshisanya, K. P. (2014). Factors Affecting Loan Repayment Performance among Members of Cooperative Thrift and Credit Society in Yewa North Local Government Area, Ogun State, Nigeria. Greener Journal of Agricultural Sciences, 4(6), 238-244. http://dx.doi.org/10.15580/GJAS.2014.6.030714135

Alabi, R. A., \& Aruna, M. B. (2005). Technical Efficiency of Family Poultry Production in Niger-Delta. Journal of Central European Agriculture, 6(4), 531-538.

Anigbogu, T. U., Onugu, C. U., Onyeugbo, B. N., \& Okoli, M. I. (2014). Determinants of loan repayment among cooperative farmers in Awkanorth L.G.A of Anambra state, Nigeria. European Scientific Journal, 10, 22.

Asante, B. O., Sefa, V. A., \& Sarpong, D. B. (2011). Determinants of small scale farmers' decision to join farmer based organizations in Ghana. African Journal of Agricultural Research, 6(1), 2273-2279.

Awoke, M. U. (2004). Factors Affecting Loan Acquisition and Repayment Patterns of Smallholder Farmers in Ika North - East of Delta State, Nigeria. Journal of Sustainable Tropical Agricultural Research, 9, 61-64.

Awunyo-Vitor, D. (2012). Determinants of Loan Repayment Default among Farmers in Brong Ahafo Region of Ghana. Journal of Development and Agricultural Economics, 4(13), 339-445.

Badiru, I. O. (2010). Review of small farmer access to Agricultural Credit in Nigeria. International Food Policy Research Institute (IFPRIP, Nigeria Strategy Support Program. Policy Note 25.

Eze, C. C., \& Ibekwe, U. C. (2007). Determinants of loan repayment under the Indigenous Financial System in Southeast, Nigeria. The Social Sciences, 2(2), 116-120, 2007.

Hill, L., \& Kau, K. (1981). Analysis of Purchasing Decision with Multivariate Probit. American Journal of Agricultural Economics, 53(5), 882-883. 
Maddala, G. S. (2005). Introduction to Econometrics (3rd ed., pp. 318-323). John Wiley \& Sons Ltd., The Atrium, Southern Gate, England.

National Bureau of Statistics (NBS). (2009). Social Statistics in Nigeria. Federal Republic of Nigeria.

National Population Commission (NPC). (2006). National Bureau of Statistics. Official Gazatte (FGP 71/52007/2,500(OL24) Abuja. Retrieved April 30, 2015, from http://www.nigerianstat.gov.ng

Odoemenem, I. U., \& Obinne, C. P. O. (2010). Assessing the factors influencing the utilization of improved cereal crop production technologies by small scale farmers in Nigeria. Retrieved from http://www.indjst.org/archive/vol.3.issue.2/innocent-17.pdf

Ojiako, I. A., Idowu, A. O., \& Blessing, C. O. (2014). Determinants of Loan Repayment Behaviour of Smallholder Cooperative Farmers in Yewa North Local Government Area of Ogun State, Nigeria: an Application of Tobit Model. Journal of Economics and Sustainable Development, 5, 16.

Oladeebo, J. O., \& Oladeebo, O. E. (2008). Determinants of loan repayment among smallholder farmers in Ogbomoso agricultural zone of Oyo State, Nigeria. Journal of Soc. Science, 17(1), 59-62.

Olagunju, F. I., \& Adeyemo, R. (2007). Determinants of repayment Decision among Small Holder Farmers in Southwestern Nigeria. Pakistan Journal of Social Sciences, 4(5), 677- 686.

Onyeagocha, S. U. O., Chidebelu, S. A. N. D., Okorji, E. C., Ukoha, A. H., Osuji, M. N., \& Korie, O. C. (2012). Determinants of Loan Repayment of Microfinance Institutions in Southeast States of Nigeria. International Journal of Social Science and Humanities, 1(1).

Otunaiya, A. O., Bamiro, O. M., \& Idowu, A. O. (2014). Determinants of rural bank loan repayment capacity among farmers in Yewa Division of Ogun State, Nigeria. International Journal of Applied Agricultural \& Apicultural Research, 10(1\&2), 33-43.

Rahji, M. A. Y., \& Fakayode, S. A. (2009). A Multinomial Logit Analysis of Agricultural Credit Rationing by Commercial Banks in Nigeria. International Research Journal of Finance and Economics, 24, 91.

Saleem, A., Ali, F., Khattak, R. M., \& Quraishi, M. I. (2014). Impact of Farm and Farmers Characteristics on Repayment of Agriculture Credit. Abasyn Journal of Social Sciences, 4(1).

Tundui, C., \& Tundui, H. (2013). Microcredit, Micro Enterprising and Repayment Myth: The Case of Micro and Small Women Business Entrepreneurs in Tanzania. American Journal of Business and Management, 2(1), 20-30. http://dx.doi.org/10.11634/216796061302240

Ugbomeh, G. M. M., Achoja, F. O., Ideh, V., \& Ofuoku, A. U. (2008). Determinants of loan repayment performance among women self help groups in Bayelsa State, Nigeria. Agriculturae Conspectus Scientificus, 73(3), 189-195.

United States Department of Agriculture (USDA). (2013). International egg and poultry review (Vol. 16, No. 8).

Wongnaa, C. A., \& Awunyo-Vitor, D. (2013). Factors Affecting Loan Repayment Performance Among Yam Farmers in the Sene District, Ghana. Agris On-Line Papers in Economics and Informatics, 5(2), 111-122.

\section{Copyrights}

Copyright for this article is retained by the author(s), with first publication rights granted to the journal.

This is an open-access article distributed under the terms and conditions of the Creative Commons Attribution license (http://creativecommons.org/licenses/by/3.0/). 